\title{
The Concept of Protection and the Rights of the Children Involved in Research
}

\author{
Lutfatulatifah \\ Program Studi Pendidikan Anak Usia Dini, Sekolah Pascasarjana, Universitas Pendidikan Indonesia, Indonesia
}

Corresponding e-mail: $\underline{\text { uul@student.upi.edu }}$

\begin{abstract}
A huge amount of research has been conducted with young children. Some research is completed by undergraduate students as part of their graduate requirement while another is conducted by early childhood education teachers as part of their career as well as professional promotion. While the discourse of children's rights in Indonesia is often overlooked, it has been actually widely argued that doing research with young children yields ethical consideration. Young children are situated as fragile human being when at the same time, they possess the same rights as possessed by adults. This paper attempts to illuminate some issues in doing research with young children. Furthermore, this paper particularly focuses on how to include children's voices in a research context within the discourse of protection.
\end{abstract}

Keywords: research, child protection, young children, children's voices

\section{INTRODUCTION}

Nowadays, a number of research whether it is in education or health fields are conducted by involving children and early children. For example, in the field of education, many research completed by students to obtain the degrees, are often done by involving children. A bachelor's degree is a minimum academic qualification for educators or teachers (Indonesian Government Regulation no 19 2005, 2005). The research that involve children and early childhood teachers is a requirement for PNS (civil servants) to do PTK (classroom action research) with the aim to improve the professionalism or promotion group (Indonesian Government Regulation no 35 2010, 2010). That research is considered acts which are only for political purposes and professionalism (Alanen, 2011; Woodhead and Faulkner, 2008). Whereas in the UN child rights convention requires that in all actions concerning children, the best interests of the child shall be a primary consideration (UNGA, 1989). Research conducted by involving children and early childhood are very sensitive and have the opportunity for exploitation (Alderson \& John,
2008; Alderson in Penn, 2005; Thomas \& O'Kane, 1998; Warin, 2011).

Children are seen as weak, helpless, and vulnerable to abuse (Fargas-Malet, McSherry, Larkin, \& Robinson, 2010; Lundahl, Nimer, \& Parsons, 2006; Powell \& Smith, 2009) so that the children need the supervision, protection, as well as control and help from parents and adults (Skolnick, 1975; Adriany, 2013). The involvement of children is not reduced only as an object, but also the subject who has a crucial role in the research (Powell \& Smith, 2009). Children can decide for their involvement in the study. As stated in the child protection laws that have been ratified after Indonesian defenders' participation in the convention of children's rights, children have the right to hold opinions and participate according to their age and stage of development (UNGA, 1989; BAL, 2002). This means that children are also seen to have the same rights as adults (Franklin, 2002).

Indonesia does not have the guidelines for research in particular yet. However, the legislation protection of children in some countries covers all aspect of children's lives included in the study including some parts on the guidelines of research involving children. One of them is United Kingdom 
that has the Ethical Guidelines for Educational Research (the British Educational Research Association, 2011). The Ethics for Research are to be applied in European countries (European Union, 2013). Australia has a National Statement on Ethical Conduct in Human Research 2007 which is updated in 2015 (The National Health and Medical Research Council and the Australian Research Council and the Australian Vice-Chancellors ' Committee, 2015), though on some countries they have the specific guidelines such as in the country of New Zealand (New Zealand Association for Research in Education, 2010). United States is one of the countries that do not follow the conventions, but has a Code of Ethics that outlines the way how to do research involving children (DISTRICT Council, 2011).

Present paper attempts to compare the rules of research that involve early childhood and the complexity of the rules which take the confusion with the need to protect children, while on the other hand the involvement of children in research is required. Furthermore, it elaborates what kind of children rights in the guidelines of the research and the extent of the involvement of children in research should be.

\section{APPRECIATION FOR CHILDREN'S RIGHTS}

The existence of some parts of the research guidelines that regulate how research involving children performed shows the appreciation for children's rights. The further appreciation of children's rights is given throughout the study, along with how the initial process involving children, then the implementation of the research, and the impact of such research after the research is done.

It is mentioned in the educational research guidelines that the consent or willingness is a part of the important rights. The study will not involve humans as participants without the willingness and the willingness of participants should be based on volunteers (AERA Council, 2011; British Educational Research Association, 2011; European Union, 2013; New Zealand Association for Research in Education, 2010; The National Health and Medical Research Council and the Australian Research Council and the Australian Vice Chancellors' Committee, 2015). Researchers should ensure that participants understand about the research that will be conducted, including how the research results will be widely accessible, and the possibility of research risks although small.
Then how to see the willingness of the child while the child's difficulty in research from the perspectives of children often cannot be understood by adults (Punch, 2002). In general, willingness for the children to be researched is expressed by parents or guardians are legally valid. Besides, in conducting research involving children, in addition to obtaining the permission of a parent, guardian, or legal law willingness is also offered to children in accordance with the capability and capacity of children. This thing is elaborated in the research guidelines for European countries in which the research that protect participants are conducted based on their proportions, so that the selection of research method should be fit with its needs. However, the child's willingness to be involved in research can be gained by having sustainable continuous consent or permission (Warin, 2011). Continuous consent is an ongoing negotiation process or a continuous basis on the child during the research process (Adriany, 2013). Because it can be licensed, the willingness given by a parent or guardian does not fairly represent the willingness of the child. Rejection involvement of children in the research is also a right that must be respected, including any time when children want to stop engaging in research.

In addition to the willingness which is a children's rights, privacy and confidentiality of the children also need to be considered, such as not publishing information relating to the background data of children or the children identity that allows it to be used to exploit or harm the child. In general, when the data of the research is collected, the researchers are obliged to disguise the identity of the research participants. Moreover, when the information is publicly available research investigators are required to ask for permission and approval of participants and related parties beforehand.

Researchers are obliged to take care of the data that have been obtained as well as protecting children who are participating from the possibilities that could harm them. As stated in the guidelines of the European research where privacy and data protection is a fundamental right that must be protected at all time (the European Union, 2013). However, when doing research with early childhood, anonymity is an option which eliminates the condition of the data with personal relationships. 


\section{FORMS OF INVOLVING CHILDREN IN RESEARCH}

Research basically should be based on mutual trust and respect. In children, this can be done by the researchers with building closeness and comfort with the child as a subject (Warin, 2011). This is also conveyed by the British Educational Research Association (2011) in which stated that research involving children should create a sense of comfort during the process, so it would not cause distress or pressure. However, in order to make children like to be involved in the study, it is necessary to build a sense of comfort.

The involvement of children in the study clearly stated in the research guidelines British Educational Research Association (2011) in which the participant is a research object whose interactions are monitored and analysed. Therefore, the child's involvement is limited as the object. However, with the appreciation of the rights of children such as giving children the opportunity to argue, it means that children not only become the object but also have an important role in the research. It includes deciding to what extent will be involved in research and determine the collection methods in research. In other words, the child is not only an object but also has a crucial role in the research (Powell \& Smith, 2009; Tay-lim \& Lim, 2013; Woodhead and Faulkner, 2008).

In giving a role to the children in the research, researchers would need a good understanding of the children. This understanding is not only about the children development but also the cultural background of the children themselves. Whereas one child with other children with different situations, cultures and backgrounds is not possible to get the same treatment. So, the involvement of children in cross-disciplinary research should consider the cultural, economic, language, health, and social relationships of early childhood and children so that their rights are not under pressure because of his position in community (Nieuwenhuys, 2008). This is similar with the statement of New Zealand Association for Research in Education (2010) in which the researchers should appreciate the diversity of children's backgrounds.

\section{CONCLUSIONS}

In general, the appreciation of children's rights is given in the research guide upholds the individual rights and responsibilities. It requires researchers to provide protection to children while maintaining the interests of the child. Additionally, the form of children's rights and the extent of the involvement of children in the study requires the researchers to consider the cultural background of the children who are not the same.

Indonesia itself has a different cultural background from either UK, Europe, America, Australia and New Zealand. As a consequence, the question how the research involves early childhood in Indonesia still remaining, because Indonesia does not have specific guidance books, whereas the trend to research with early childhood in Indonesia itself began to grow. Therefore, the recommendation that can be given in this paper is the need to conduct research in Indonesia with regard to the involvement of young children in the research.

\section{REFERENCES}

Adriany, V. (2013). Hak Anak Dalam Konteks Penelitian. In Konferensi Pendidikan Anak Usia Dini dan Pendidikan Dasar SPs UPI “Menyongsong Generasi Emas 2045" (pp. 579-585). Ed. Hartati, T., Agustin, M., \& Somantri, M. Bandung: Program Studi Pendidikan Dasar.

AERA Council. (2011). Code of Ethics American Eductional REsearch Association. Eduactional Researcher. http://doi.org/10.3102/0013189X11410403

Alanen, L. (2011). Editorial: Critical Childhood Studies? Childhood, 18(2), 147-150. http://doi.org/10.1177/0907568211404511

Alderson, P., \& John, M. (2008). Young Children's Rights: (pp. 474-475).

British Educational Research Association. (2011). ETHICAL GUIDELINES FOR EDUCATIONAL RESEARCH. London.

European Union. (2013). Ethic for researchers. Luxembourg: Office of the European Union.

Fargas-Malet, M., McSherry, D., Larkin, E., \& Robinson, C. (2010). Research With Children: Methodological Issues and Innovative Techniques. Journal of Early Childhood Research, 8(2), 175-192. http://doi.org/10.1177/1476718X09345412

Franklin, B. (Ed.). (2002). The New Handbook of Children's Rights; Comparative policy and practice. London and New York: Routledge.

Lundahl, B. W., Nimer, J., \& Parsons, B. (2006). Preventing Child Abuse: A Meta-Analysis of Parent Training Programs. Research on Social 
Work Practice, 16(3), 251-262.

http://doi.org/10.1177/1049731505284391

New Zealand Association for Research in Education. (2010). NZARE Ethical Guidelines.

Nieuwenhuys, O. (2008). Editorial: The ethics of children's rights. Childhood, 15(1), 4-11. http://doi.org/10.1177/0907568207086941

Penn, H. (Ed.). (2005). Understanding Early Childhood: Issues and Controversies. New York: Open University Press.

Permen no 19 tahun 2005. (2005). Standar Nasional Pendidikan.

Permen no 35 th 2010. (2010). Peraturan Menteri Pendidikan Nasional nomor 35 tahun 2010 tentang petunjuk teknis pelaksanaan jabatan fungsional guru dan angka kreditnya. Jakarta.

Powell, M. A., \& Smith, A. B. (2009). Children's Participation Rights in Research. Childhood, 16(1), 124-142. http://doi.org/10.1177/0907568208101694

Punch, S. (2002). The same or different from research with adults? Sagepub, 9(3), 321-341.

Skolnick, A. (1975). THE LIMITS OF CHILDHOOD : CONCEPTIONS OF CHILD DEVELOPMENT AND SOCIAL CONTEXT. In Law and Contemporary Problems (Vol. 509, pp. 38-77).

Tay-lim, J., \& Lim, S. (2013). Privileging Younger Children's Voices in Res earch : Use of Drawings and a Co- Construction Process. International Journal of Qualitative Methods, $12,65-83$.

The National Health and Medical Research Council and Australian Research Council and the Australian Vice -Chancellors' Committee. (2015). National Statement on Ethical Conduct in Human Research 2007 (Vol. 2007). Canberra: The National Health and Medical Research Council.

Thomas, N., \& O'Kane, C. (1998). The ethics of participatory research with children. Children \& Society, 12(5), 336-348.

http://doi.org/10.1111/j.10990860.1998.tb00090.x

UNGA. (1989). Convention on the Rights of the Child: Adoted by General Assembly of The United Nations, 20 November 1989.

UUPA. (2002). Undang-Undang Republik Indonesia Nomor 23 Tahun 2002 Tentang Perlindungan Anak. Jakarta.

Warin, J. (2011). Ethical Mindfulness and Reflexivity: Managing a Research
Relationship With Children and Young People in a 14-Year Qualitative Longitudinal Research (QLR) Study. Qualitative Inquiry, 17(9), 805-814. http://doi.org/10.1177/1077800411423196 Woodhead, M., \& Faulkner, D. (2008). Research with children: perspectives and practices. ( $\mathrm{P}$. Christensen \& A. James, Eds.), Archives of medical research (Second, Vol. 33). New York and London: Routledge. 